\title{
Performance evaluation of a formulated infant food on some biological indices in Wistar rats
}

\author{
Chris Oche IKESE ${ }^{*}{ }^{1}$ Simon Terver UBWA, ${ }^{1}$ Peter Agorye ADIE, ${ }^{1}$ Steven Inegedu AUDU, ${ }^{2}$ and \\ Godwin EJEKE ${ }^{1}$
}

${ }^{1}$ Department of Chemistry, Benue State University, Makurdi 970222, Nigeria

${ }^{2}$ Department of Chemistry, Nasarawa State University, Keffi 961101, Nigeria

\begin{abstract}
Performance evaluation of a formulated infant food on some biological indices in Wistar rats was investigated. For rats fed separately with normal rat feed, formulated infant food and proprietary food, serum total protein and albumin were determined by colorimetric method, red blood cell (RBC) and differential white blood cell (WBC) counts were determined with a haemocytometer, packed cell volume (PCV) was by micro-haematocrit, haemoglobin (HGB) was determined using cyanomethaemoglobin method while mean cell volume (MCV) and mean cell haemoglobin (MCH) were calculated. The results obtained showed that, for Wistar rats fed with normal rat feed, the baseline values prior to the commencement of feeding trial for serum total protein, albumin, body weight, PCV, WBC, platelet count (PLT), RBC, HGB, lymphocyte count (LYM), MCH, MCV, neutrophil (NEU), and eosinophil (EOS) were $82.9 \mathrm{~g} / \mathrm{dL}, 44.75 \mathrm{~g} / \mathrm{dL}$, $142.80 \mathrm{~g}, 41.14 \%, 7.60 \times 10^{3} \mu \mathrm{L}^{-1}, 404.85 \times 10^{3} \mu \mathrm{L}^{-1}, 5.68 \times 10^{6} \mu \mathrm{L}^{-1}, 10.80 \mathrm{~g} / \mathrm{dL}, 50.28 \%, 18.42 \mathrm{pg}, 59.28 \mathrm{fL}, 45.57 \%$, and $2.57 \%$ respectively. After the feeding trial, the serum total protein, albumin, body weight, PCV, WBC, PLT, RBC, HGB, LYM, MCH, MCV, NEU, and EOS in Wistar rats fed with the formulated infant food (the experimental group) were 79.6 $\mathrm{g} / \mathrm{dL}, 50.65 \mathrm{~g} / \mathrm{dL}, 169.18 \mathrm{~g}, 40.14 \%, 5.77 \times 10^{3} \mu \mathrm{L}^{-1}, 309.85 \times 10^{3} \mu \mathrm{L}^{-1}, 6.85 \times 10^{6} \mu \mathrm{L}^{-1}, 12.45 \mathrm{~g} / \mathrm{dL}, 52.85 \%, 18.24 \mathrm{pg}$, $58.64 \mathrm{fL}, 42.00 \%$, and $2.14 \%$ respectively and these were in most cases, either greater or comparable with their corresponding mean values of $69.1 \mathrm{~g} / \mathrm{dL}, 44.40 \mathrm{~g} / \mathrm{dL}, 177.97 \mathrm{~g}, 30.24 \%, 4.18 \times 10^{3} \mu \mathrm{L}^{-1}, 188.14 \times 10^{3} \mu \mathrm{L}^{-1}, 5.29 \times 10^{6} \mu \mathrm{L}^{-1}$, $10.74 \mathrm{~g} / \mathrm{dL}, 53.14 \%, 20.37 \mathrm{pg}, 57.61 \mathrm{fL}, 38.85 \%$, and $4.57 \%$ respectively in Wistar rats fed with the proprietary infant formula (the control group). This shows that the potential infant food has a more positive effect on most of the biological indices assessed than the proprietary infant food or a comparable effect at the least.
\end{abstract}

Keywords: formulated infant food, Wistar rats, biological indices, infant.

\section{Introduction}

Infant malnutrition continues to persist in Africa as a result of widespread poverty, inadequate knowledge on infant feeding, nutritional inadequacies of unproven traditional food formulations adapted for infant feeding [1-4] among others. Low-income families are often unable to afford nutrient-laden proprietary infant formulae. Instead, they depend on poorly processed and untested traditional cereal-legume porridges which are mostly deficient in essential nutrients for the growing infant $[2,5]$. This situation worsens as the number of families which live below the poverty line in developing countries continue to grow. Related studies $[6,7]$ have shown that the adverse effects of such unproven diet formulations on some biological indices of growth and development such as body mass and height are among the most common indicators of infant malnutrition. Similarly, a number of authors have reported adverse changes in the hematologic profile of persons suffering from malnutrition [8-10].

Globally approximately 155 million children under the age of 5 suffer from stunting. These children begin their lives at a marked disadvantage as they face learning difficulties in school, and face barriers to participation in their communities [6]. This trend has necessitated several research efforts targeted at developing low-cost infant foods [1, 2, 11-17] for low-income families. However, such efforts can only be deemed successful after a performance evaluation of such a food formulation via an animal trial that provides empirical evidence of the nutritional adequacy of the new food formulation. It is why this study is aimed at comparing the effect of a formulated infant food on some biological indices in Wistar rats vis-à-vis those of a proven proprietary infant formula. This study is aimed at ascertaining the performance of a formulated infant food so as to prevent the use of a low performance infant food as an alternative to high performance proprietary formula in infant feeding and thus aiding in the fight against infant malnutrition.

\section{Experimental}

\subsection{Feed materials and infant food formulation}

Proprietary infant formula, standard rat feed, soybean, red sorghum, rice grains and crayfish were purchased from the central market in Makurdi metropolis. The grains were processed into flours as illustrated in Figures 1 - 4 and thereafter, soybean, red sorghum, rice, crayfish and milk flavour flours were blended together according to the ratio $62.87 \%: 4.41 \%: 31.72 \%: 0.5 \%$ : $0.5 \%$ which was derived by simultaneous equation and

\footnotetext{
* Correspondence author. E-mail address: ichris@bsum.edu.ng (Chris O. Ikese)
} 
mass balance as described in a related study [1] to obtain the formulated infant food.

\subsection{Characterization of infant foods}

Both the formulated and proprietary infant foods were characterised by proximate analysis. Moisture, ash, crude fat, crude fibre and crude protein contents were determined by oven-drying, dry-ashing, Soxhlet extraction, hydrolysis and micro-Kjeldahl methods respectively using AOAC [18] standard methods. Total carbohydrate was obtained by difference $[1,12]$.

\subsection{Animal procurement and acclimatization}

Twenty-one healthy Wistar rats aged 2 weeks were procured from the Benue State University, College of Health Science Animal House. The rats were acclimatized by feeding them for 4 weeks with standard rat feed and portable drinking water ad-libitum. Seven of the rats were randomly selected and baseline values of the following biological indices: total serum protein, serum albumin, body weight, PCV, WBC, platelet count (PLT), RBC, HGB, lymphocyte count (LYM), MCH, MCV, neutrophil (NEU), and eosinophil (EOS) were determined as described in sections 2.4 and 2.5. The remaining Wistar rats were then separated using cages into experimental and positive control groups, with each comprising 7 Wistar rats for the feeding trial.

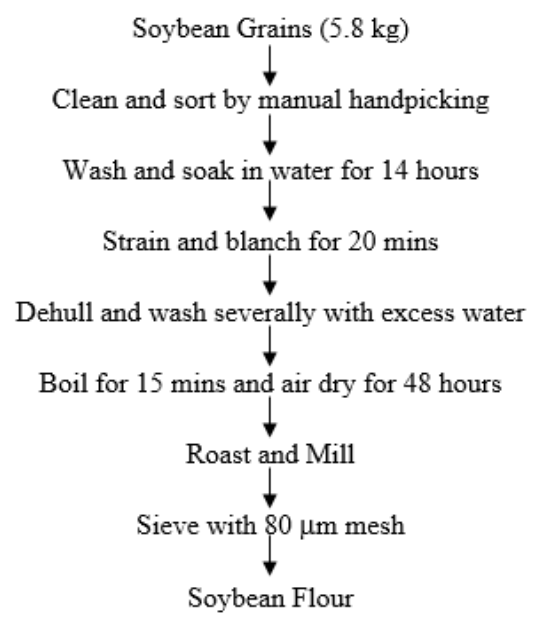

Figure 1. Preparation of soybean flour.

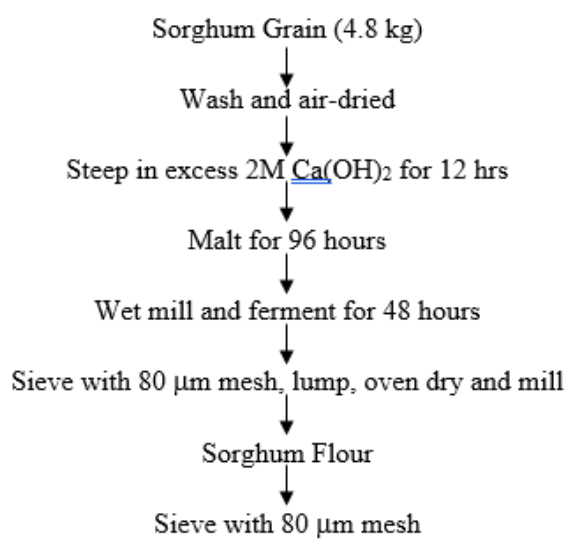

Figure 2. Preparation of sorghum flour.

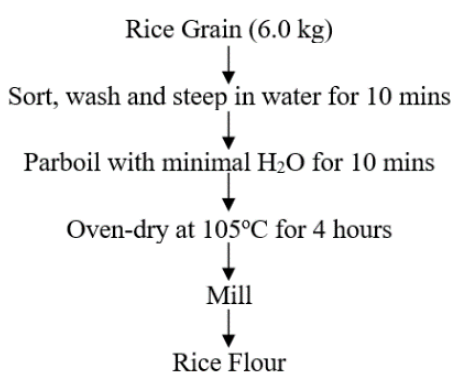

Figure 3. Preparation of rice flour.

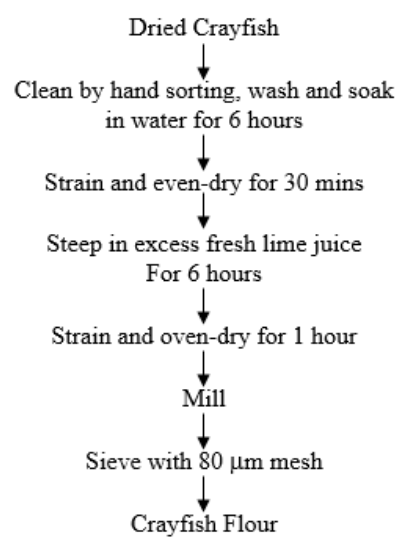

Figure 4. Preparation of crayfish flour.

\subsection{Characterization of biological indices in rats}

2.4.1. Determination of total protein. The total protein determination kit supplied by RANDOX $^{\circledR}$ was used. Twenty micro litres of Wistar rat serum was pipette into $1000 \mu \mathrm{L}$ of the colour-forming reagent, mixed and incubated at $20{ }^{\circ} \mathrm{C}$ for 10 minutes. The sample and standard absorbances were measured against the reagent blank within 30 minutes using a Lovibond ${ }^{\mathrm{TM}} 180270$ colorimeter at $580 \mathrm{~nm}$ [19].

2.4.2. Determination of serum albumin. $10 \mu \mathrm{L}$ of rat serum was added to $1000 \mu \mathrm{L}$ of bromocresol-green reagent, mixed and incubated at $20^{\circ} \mathrm{C}$ for 5 minutes. The absorbance of the sample and standard were measured at $578 \mathrm{~nm}$ against the reagent blank within 30 minutes using a colorimeter [20].

2.4.3. Determination of total and differential white blood cell count. Total white blood cell count (WBC). and differential white blood cell count - neutrophils (NEU) and eosinophils (EOS) were determined as described by Obeagu et. al [9].

2.4.4. Determination of red blood cell (RBC) count. RBC count was determined using a Neubauer counting chamber (BLAUBRAND ${ }^{\circledR}$ Model 717810) as described by Obeagu et al. [9].

2.4.5. Determination of packed cell volume (PCV). The packed cell volume was determined by the microhematocrit method as described by Obeagu et al. [9].

2.4.6. Determination of haemoglobin content. A haemoglobinometer (HEMOCUE Hb 301) was used for the determination. This was achieved by the addition of $0.03 \mathrm{~mL}$ of rat blood to $20 \mathrm{~mL}$ of $10 \mathrm{~N} \mathrm{HCl}$ in a test tube, stirring and allowing to stand for 5 minutes in order to 
convert haemoglobin to haematin. More $\mathrm{HCl}$ was added and the mixture stirred until the colour became similar to that of the haemoglobin standard. The level of the fluid in the tube was read and the haemoglobin content expressed in percentage.

2.4.7. Determination of mean corpuscular haemoglobin $(\mathrm{MCH})$. The mean corpuscular haemoglobin was calculated using) was calculated as described by Walker et al. [21].

2.4.8. Determination of platelet count (PLT). Platelet count was determined as described by Obeagu et al. [9].

2.4.9. Determination of lymphocyte count (LYM). Lymphocytes were determined from a smear of blood made on a glass slide as described by Obeagu et al. [9].

2.4.10. Determination of mean corpuscular volume $(M C V)$. The mean corpuscular volume (MCV) was calculated as described by Walker et al. [21].

\subsection{Feeding trial}

Wistar rats in the experimental and control groups were fed with formulated infant food and proprietary infant formula respectively for 42 days ad-libitum. Thereafter, the body weight of all the rats were measured, recorded and their means calculated. The rats in both groups were then sacrificed by jugular incision and their blood collected and labelled according to group. Total serum protein, albumin, PCV, WBC, PLT, RBC, HGB, lymphocyte count (LYM), MCH, MCV, neutrophil (NEU), and eosinophil (EOS) were determined for each rat as described previously. The mean value of these parameters in both the experimental and control groups were calculated.

\subsection{Statistical analysis}

The mean of each biological index measured for baseline, experimental and control groups were compared by one-way ANOVA using IBM SPSS statistics software, version 25.0 to ascertain if they were significantly different.

\section{Results and discussion}

Table 1 shows the proximate compositions of both the proprietary infant formula and the formulated infant food.

From the results in Table 1, both proprietary infant food and the formulated infant food in most cases approximate the United Nation's Protein Advisory Group (PAG) recommendations for infant food composition [22], hence suggesting the suitability of the formulated food for infant feeding. Although each corresponding food components of the formulated infant food is not exactly the same in magnitude with that of the proprietary infant formula, they are not significantly different when statistically compared. The implication is that both feeds will likely give a similar performance in a feeding experiment. Similarly, the protein content of the formulated food $(13.59 \%)$ is less than the PAG benchmark for protein $(20 \%)$ in infant food, but it is higher than the mean protein content in both proprietary formulae (12.47\%). However, since there are no documented cases of protein-energy malnutrition in infants fed with the proprietary formula over the years despite having a lower protein content than the PAG benchmark, it is plausible to expect that the formulated food given its higher crude protein content to produce an even better performance. A similar explanation holds with respect to crude fat content.

Table 1. Proximate composition of proprietary infant formula and formulated infant food in comparison with PAG recommendation [22].

\begin{tabular}{|c|c|c|c|c|}
\hline $\begin{array}{l}\mathbf{S} / \\
\mathbf{N}\end{array}$ & Component & $\begin{array}{l}\text { Formulated } \\
\text { infant food }\end{array}$ & $\begin{array}{c}\text { Proprietary } \\
\text { infant } \\
\text { formula }\end{array}$ & PAG \\
\hline 1. & $\begin{array}{l}\text { Moisture } \\
\text { content }(\%)\end{array}$ & $5.01^{\mathrm{a}} \pm 0.84$ & $3.55^{\mathrm{a}} \pm 0.24$ & $5-10$ \\
\hline 2. & $\begin{array}{l}\text { Ash content } \\
(\%)\end{array}$ & $2.66^{\mathrm{b}} \pm 0.14$ & $1.22^{\mathrm{b}} \pm 0.34$ & $\leq 5$ \\
\hline 3. & $\begin{array}{l}\text { Crude protein } \\
(\%)\end{array}$ & $13.59^{c} \pm 2.23$ & $12.47^{\mathrm{c}} \pm 1.14$ & 20 \\
\hline 4. & $\begin{array}{l}\text { Crude fiber } \\
(\%)\end{array}$ & $1.87^{\mathrm{d}} \pm 0.72$ & $2.24^{\mathrm{d}} \pm 0.21$ & $<5$ \\
\hline 5. & Crude fat $(\%)$ & $5.92^{\mathrm{e}} \pm 1.26$ & $3.88^{\mathrm{e}} \pm 1.41$ & 10 \\
\hline 6. & $\begin{array}{l}\text { Total } \\
\text { carbohydrate } \\
(\%)\end{array}$ & $70.75^{\mathrm{f}} \pm 0.24$ & $76.64^{\mathrm{f}} \pm 3.25$ & 65 \\
\hline
\end{tabular}

Values are means \pm standard deviations of triplicate determinations. Means with identical superscripts in a row are not significantly different at $p<0.05$.

Also, moisture content is higher in the formulated infant food $(5.01 \%)$ than it is in the proprietary formula $(3.55 \%)$. This suggests that the former will be more prone to microbial spoilage than the latter. However, both feeds have a lower moisture content than the mean moisture content in all three diet formulations $(7.25 \%)$ reported by Ehimen et al. [23].

Table 2. Biological indices of Wistar rats fed with formulated infant food, proprietary formula and their baseline values.

\begin{tabular}{|c|c|c|c|}
\hline S/N Parameters & $\begin{array}{l}\text { e rats fed with vita rich } \\
\text { normal rat feed) }\end{array}$ & $\begin{array}{l}\text { Rats fed with infant food } \\
\text { (formulated infant food) }\end{array}$ & $\begin{array}{r}\text { Rats fed with NAN } \\
\text { (proprietary food) }\end{array}$ \\
\hline 1. Albumin (g/dL) & $44.75^{\mathrm{e}} \pm 5.08$ & $50.65^{\mathrm{d}} \pm 2.16$ & $44.40^{\mathrm{f}} \pm 11.15$ \\
\hline 2. Weight (g) & $142.80^{\mathrm{abc}} \pm 8.9$ & $169.18^{\mathrm{ab}} \pm 16.0$ & $177.97^{\mathrm{ac}} \pm 17.83$ \\
\hline 3. Protein $(\mathrm{g} / \mathrm{dL})$ & $82.9^{\mathrm{ac}} \pm 7.99$ & $79.6^{\mathrm{bc}} \pm 6.23$ & $69.1^{\mathrm{abc}} \pm 4.46$ \\
\hline 4. Packed cell volume (\%) & $41.14^{\mathrm{ac}} \pm 5.78$ & $40.14^{\mathrm{bc}} \pm 4.94$ & $30.24^{\mathrm{abc}} \pm 4.27$ \\
\hline 5. Platelet count $\left(\times 10^{3} / \mu \mathrm{L}\right)$ & $404.85^{\mathrm{ac}} \pm 114.76$ & $309.85^{\mathrm{e}} \pm 133.59$ & $188.14^{\mathrm{ac}} \pm 117.52$ \\
\hline 6. white blood cell count $\left(\times 10^{3} / \mu \mathrm{L}\right)$ & $7.60^{\mathrm{ac}} \pm 2.62$ & $5.77^{\mathrm{e}} \pm 1.84$ & $4.18^{\mathrm{ac}} \pm 2.14$ \\
\hline 7. Red blood cell count $\left(\times 10^{6} / \mu \mathrm{L}\right)$ & $5.68^{\mathrm{e}} \pm 2.16$ & $6.85^{\mathrm{d}} \pm 0.844$ & $5.29^{\mathrm{f}} \pm 0.80$ \\
\hline 8. Haemoglobin (g/dL) & $10.80^{\mathrm{e}} \pm 3.72$ & $12.45^{\mathrm{d}} \pm 1.34$ & $10.74^{\mathrm{e}} \pm 1.80$ \\
\hline 9. Lymphocyte (\%) & $50.28^{\mathrm{f}} \pm 9.06$ & $52.85^{\mathrm{d}} \pm 8.27$ & $53.14^{\mathrm{d}} \pm 18.53$ \\
\hline
\end{tabular}




\begin{tabular}{lccc}
\hline S/N Parameters & $\begin{array}{c}\text { Baseline rats fed with vita rich } \\
\text { (normal rat feed) }\end{array}$ & $\begin{array}{c}\text { Rats fed with infant food } \\
\text { (formulated infant food) }\end{array}$ & $\begin{array}{c}\text { Rats fed with NAN } \\
\text { (proprietary food) }\end{array}$ \\
\hline 10. Mean corpuscular haemoglobin (pg) & $18.42^{\mathrm{f}} \pm 3.92$ & $18.24^{\mathrm{f}} \pm 1.28$ & $20.37^{\mathrm{d}} \pm 4.41$ \\
11. Mean cell volume (fL) & $59.28^{\mathrm{d}} \pm 3.18$ & $58.64^{\mathrm{e}} \pm 1.76$ & $57.61^{\mathrm{f}} \pm 1.67$ \\
12. Neutrophil (\%) & $45.57^{\mathrm{d}} \pm 9.36$ & $42.00^{\mathrm{e}} \pm 8.90$ & $38.85^{\mathrm{f}} \pm 19.72$ \\
13. Eosinophil (\%) & $2.57^{\mathrm{e}} \pm 1.98$ & $2.14^{\mathrm{f}} \pm 0.899$ & $4.57^{\mathrm{d}} \pm 3.40$ \\
\hline
\end{tabular}

Values are means \pm standard deviations of triplicate determinations.

Means with identical superscripts in a row are not significantly different at $p<0.05$.

Table 2 shows the baseline values of some biological indices in Wistar rats, the values of these indices in Wistar rats when fed with the formulated infant food, and with proprietary infant formula.

From Table 2, it can be seen that serum albumin, body weight, RBC count, HGB and lymphocytes counts increased above their initial baseline values in rats fed with the formulated infant food. These increments suggest that the formulated infant food will likely raise these indices in infants fed with it.

Table 2 shows that in rats fed with the formulated infant food, the values for NEU, MCV, HGB, WBC, PLT, PCV, total serum protein and serum albumin $(50.65 \mathrm{~g} / \mathrm{dL})$ were higher than their corresponding values in rats fed with the proprietary infant formula. These suggest that the formulated infant food if fed to infants, may yield better performance with respect to the aforementioned parameters when compared with the proprietary formula. However, it is important to note that the expected improvement may only be marginal as observed in the study.

Table 2 also shows that the values for total protein, PCV, PLT, WBC, MCV and NEU fell below their corresponding baseline values both in rats fed with the formulated infant food and rats fed with the proprietary infant formula. This suggests that with respect to the said parameters, the standard rat feed performed better than both proprietary infant formula and the formulated infant food. This may be due to nutrient losses associated with the food processing methods involved in the preparation of highly refined infant foods. This is not the case with standard rat feed. The range of values obtained for the biological indices assessed were found to be similar to those reported in similar studies and related literature $[1,24,25]$ thus justifying similar conclusions reached.

\section{Conclusion}

The study found that the formulated infant food had a more positive impact than the proprietary infant formula in increasing serum albumin, total protein, PCV, PLT, HGB and NEU levels in the experimental subjects. However, there was no significant difference between the impact of the formulated infant food and the proprietary infant formula on $\mathrm{RBC}, \mathrm{WBC}, \mathrm{MCH}$ and MCV.

With the exception of serum albumin, body weight and EOS, it is clear that the formulated infant food and the proprietary formulae were unable to sustain the baseline values of the assessed biological indices as their values declined both in the experimental and control groups at the end of the feeding regimen, so that the feed performance is in the order standard rat feed > formulated infant food $>$ proprietary formula.

\section{Conflict of interest}

The authors declare that there is no conflict of interest.

\section{References}

[1]. C.O. Ikese, P.C. Okoye, S.T. Ubwa, S. Akende, Proximate analysis and formulation of infant food from soybean and cereals obtained in Benue State, Nigeria, International Journal of Food Science and Biotechnology 5 (2017) 106-113.

[2]. K.J. Ahima, Formulation of weaning foods using composite of maize, groundnut and soya bean and assessing its nutritional effects using animal model (Unpublished M.Sc. thesis), Department of Biochemistry and Biotechnology Kwame Nkrumah University of science and technology, Ghana pp. 1-78 (2008).

[3]. J.B. Fashakin, F. Ogunsoola, The utilization of local foods in fermentation of weaning foods, Journal of Tropical Pediatrics 28 (1982) 93-96.

[4]. D.J. Naismith, Kwashiorkor in Western Nigeria: a study of traditional weaning foods with particular respect to energy and linoleic acid, British Journal of Nutrition 80 (1973) 567-76.

[5]. C. Hotz, R.S. Gibson, Traditional food-processing and preparation practices to enhance the bioavailability of micronutrients in plant-based diets, The Journal of Nutrition 4 (2007) 10971100.

[6]. E. Agyepong, A. Valle, Improvement of weaning practices for the future, Bulletin of Noguchi, Memorial Institute for Medical Research 4 (1991) 82-92.

[7]. T.O. Akinele, B.O. Omotola, Energy and protein intake of infants and children from the low-income group of Ibadan, Nutrition Research 26 (1986) 129-137

[8]. A.O. Saka, M.J. Saka, A. Ojuawo, A. Abdulkarim, S.A. Bilamin, L. Latubosun, M. Adeboye, Haematological Profile in Children with Protein Energy Malnutrition in North Central Nigeria, Global Journal of Medical Research 4 (2012) 9-13

[9]. E.I. Obeagu, K.C. Ochei, I.O. Oshim, G.U. Obeagu, Evaluation of changes in some haematological indices of malnourished infants in Umuahia, International Journal of Current Research in Biology and Medicine 2 (2017) 14-20.

[10]. P. Borelli, S. L. Blatt, M.M. Rogero, R.A. Fock, Haematological alterations in protein malnutrition, 
Revista Brasileira de Hematologia Hemoterapia 1 (2004) 49-53.

[11]. E.K. Takyi, Y. Kido, T. Rikimaru, D.O. Kennedy, The use of alfalfa as a supplement in infant feeding, Bulletin of Noguchi Memorial Institute for Medical Research 4 (1991) 35-47.

[12]. C.O. Ikese, S.T. Ubwa, S.O. Adoga, J. Lenka, J. Inalegwu, M.O. Ocheje, S.I. Audu, Proximate composition, antinutrients and some functional properties of a potential infant food made from wheat and groundnut, International Journal of Food Science and Nutrition 1 (2016) 59-63.

[13]. M. Solomon, Nutritive value of three potential complementary foods based on cereals and legumes, The African Journal of Food, Agriculture, Nutrition and Development 5 (2005) $1-14$.

[14]. J. Ejigui, L. Savoie, J. Marin, T. Desrosiers, Improvement of the nutritional quality of a traditional complementary porridge made of fermented yellow maize (Zea mays): Effect of maize-legume combinations and traditional processing methods, Food and Nutrition Bulletin 1 (2007) 23-34.

[15]. J.C. Jackson, L. Weatherspoon, M. Nnyepi, L. Malete, L. Mokgatlhe, P. Lyoka, M. Bennink, Sorghum bean composite porridge nutritional quality and acceptability, Nutrition and Food Science 5 (2013) 453-461.

[16]. M.A. Abeshu, A. Lelisa, B. Geleta, Complementary feeding: Review of recommendations, feeding practices, and adequacy of homemade complementary food preparations in developing countries lessons from Ethiopia, Frontiers in Nutrition 3 (2016) 1-9.

[17]. F.K. Amagloh, T. Chiridza, M.E. Lemercier, A. Broomfield, P.C.H. Morel, J. Coad, Sweet potato and cereal-based infant foods: protein quality assessment, and effect on body composition using sprague Dawley rats as a model, PLOS ONE 4 (2015) 1-11.
[18]. AOAC, Official Methods of Analysis. Association of Official Analytical Chemists, 18th Edition, Arlington, pp. 806-842 (2012).

[19]. C.O. Ikese, D.T. Kukwa, J.L. Lenka, S.O. Adoga, Comparative study of total cholesterol and total protein levels of chicken and quail eggs produced in Benue State-Nigeria, International Journal of Current Research in Chemistry and Pharmaceutical Sciences 2 (2015) 74-78.

[20]. F.L. Rodkey, Direct spectrophotometric determination of albumin in human serum, Clinical Chemistry 2 (1965) 479-487.

[21]. H.K. Walker, W.D. Hall, J.W. Hurst, Clinical Methods: The History, Physical, and Laboratory Examinations, 3rd edition, Boston, Butterworths, pp. 721-723 (1990).

[22]. C.O. Ikese, P.A.C. Okoye, S.T. Ubwa, S. Akende, Proximate analysis and formulation of infant food from soybean and cereals obtained in Benue State, Nigeria, International Journal of Food Science and Biotechnology 5 (2017) 106-113.

[23]. R.O. Ehimen, A.A. Abiodun, A.I. Michael, P.S. Olajide, A.T. Afolabi, R.O. Ishola, S.O. Ayansina, O.O. Tolulope, F. Ayorinde, Nutrient composition, functional and pasting properties of unripe cooking banana, Pigeon pea and sweet Potato flour blends, Journal of food science and Nutrition 5 (2017) 754755.

[24]. S. Fuggle, Clinical biochemistry reference ranges, Eastbourne District General Hospital \& Conquest Hospital, Hastings, NHS Trust 10 (2018) 3-18.

[25]. Y. Asano, M. Susami, K. Honda, T. Serikawa Haematological and serum biochemical values in spontaneously epileptic male rats and related rat strains, Journal of Agriculture and Life Sciences 32 (1998) 214-218.

Received: 28.08.2019

Received in revised form: 10.11.2019

Accepted: 12.11.2019 